\title{
Teaching NeuroImages: Corkscrew medullary veins in active neurosarcoidosis
}

Michael T. Caton, Jr., MD, Wai-Ying Wendy Yau, MD, Raymond Y. Huang, MD, PhD, and Shamik Bhattacharyya, MD

Neurology ${ }^{\circledR}$ 2019;93:e1832-e1833. doi:10.1212/WNL.0000000000008460

Figure Fluid-attenuated inversion recovery (FLAIR), gadolinium contrast-enhanced, and susceptibility-weighted images

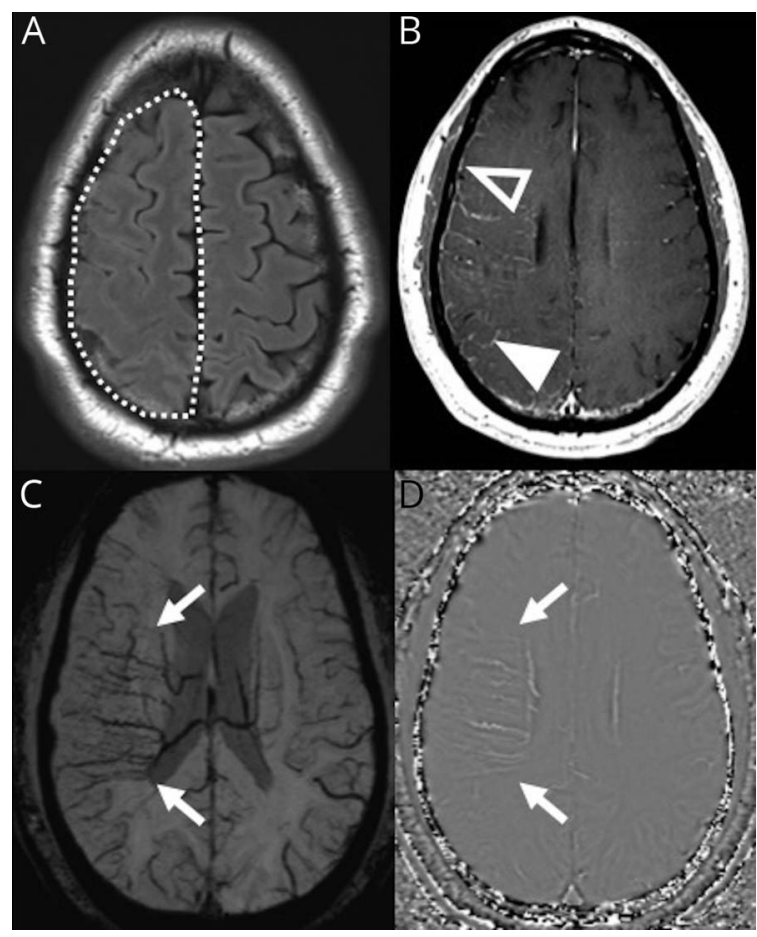

(A) FLAIR images show asymmetric gyral edema of the right frontal and parietal lobes (dotted line). (B) Both pial (clear arrowhead) and dural (solid arrowhead) enhancement were seen throughout the right hemisphere. (C) Susceptibilityweighted images show dilated and tortuous right-sided medullary veins (white arrows), confirmed on phase-contrast imaging (D).

A 47-year-old man with a history of biopsy-proven sarcoidosis presented with 6 months of cognitive decline and incontinence. Neuroimaging was consistent with active neurosarcoidosis and notable for asymmetrical dilation and corkscrew appearance of the right medullary veins (figure). Medullary vein dilation is a recently described imaging pattern in neurosarcoidosis, seen in $33 \%$ of patients. ${ }^{1}$ The pathogenesis is uncertain but may result from perivenous inflammation or dysfunction of glymphatic drainage. ${ }^{1}$ Susceptibility-weighted imaging highlights the veins by localizing the paramagnetic signal of deoxygenated blood. ${ }^{2}$ Medullary vein dilation is a frequent finding in neurosarcoidosis, which can be used as one of the diagnostic criteria and can serve as a biomarker of disease activity.

\author{
Correspondence \\ Dr. Caton \\ travis.caton@gmail.com
}

\section{Study funding}

No targeted funding reported. 


\section{Appendix Authors}

\begin{tabular}{llll}
\hline Name & Location & Role & Contribution \\
\hline $\begin{array}{l}\text { Michael Travis } \\
\text { Caton Jr., MD }\end{array}$ & $\begin{array}{l}\text { Brigham and } \\
\text { Women's } \\
\text { Hospital, } \\
\text { Boston, MA }\end{array}$ & Author & $\begin{array}{l}\text { Designed and } \\
\text { conceptualized study, } \\
\text { interpreted the data, } \\
\text { drafted the manuscript } \\
\text { for intellectual content }\end{array}$ \\
$\begin{array}{l}\text { Wai-Ying } \\
\text { Wendy Yau, MD }\end{array}$ & $\begin{array}{l}\text { Brigham and } \\
\text { Women's } \\
\text { Hospital, } \\
\text { Boston, MA }\end{array}$ & Author & $\begin{array}{l}\text { Analyzed the data, } \\
\text { revised the manuscript } \\
\text { for intellectual content }\end{array}$ \\
$\begin{array}{l}\text { Raymond Y. } \\
\text { Huang, MD, PhD }\end{array}$ & $\begin{array}{l}\text { Brigham and } \\
\text { Women's } \\
\text { Hospital, } \\
\text { Boston, MA }\end{array}$ & Author & $\begin{array}{l}\text { Analyzed the data, } \\
\text { revised the manuscript } \\
\text { for intellectual content }\end{array}$ \\
$\begin{array}{l}\text { Shamik } \\
\text { Mhattacharyya, } \\
\text { MD }\end{array}$ & $\begin{array}{l}\text { Brigham and } \\
\text { Women's } \\
\text { Hospital, } \\
\text { Boston, MA }\end{array}$ & Author & $\begin{array}{l}\text { Designed and } \\
\text { conceptualized study, } \\
\text { interpreted the data, } \\
\text { revised the manuscript } \\
\text { for intellectual content }\end{array}$ \\
\hline
\end{tabular}

\section{Disclosure}

The authors report no disclosures relevant to the manuscript. Go to Neurology.org/N for full disclosures.

\section{References}

1. Zamora C, Hung S-C, Tomingas C, Atkinson C, Castillo M. Engorgement of deep medullary veins in neurosarcoidosis: a common-yet-underrecognized cerebrovascular finding on SWI. AJNR Am J Neuroradiol 2018;39:2045-2050.

2. Haacke EM, Mittal S, Wu Z, Neelavalli J, Cheng YC. Susceptibility-weighted imaging: technical aspects and clinical applications, part 1. Am J Neuroradiol 2009;30:19-30. 


\section{Neurology}

Teaching NeuroImages: Corkscrew medullary veins in active neurosarcoidosis Michael T. Caton, Jr, Wai-Ying Wendy Yau, Raymond Y. Huang, et al. Neurology 2019;93; 1832 -e1833

DOI 10.1212/WNL.0000000000008460

This information is current as of November 4, 2019

\section{Updated Information \&} Services

References

Subspecialty Collections

Permissions \& Licensing

\section{Reprints}

including high resolution figures, can be found at: http://n.neurology.org/content/93/19/e1832.full

This article cites 2 articles, 2 of which you can access for free at: http://n.neurology.org/content/93/19/e1832.full\#ref-list-1

This article, along with others on similar topics, appears in the following collection(s):

All Cerebrovascular disease/Stroke

http://n.neurology.org/cgi/collection/all_cerebrovascular_disease_strok e

All Immunology

http://n.neurology.org/cgi/collection/all_immunology

MRI

http://n.neurology.org/cgi/collection/mri

Vasculitis

http://n.neurology.org/cgi/collection/vasculitis

Information about reproducing this article in parts (figures,tables) or in its entirety can be found online at:

http://www.neurology.org/about/about_the_journal\#permissions

Information about ordering reprints can be found online:

http://n.neurology.org/subscribers/advertise

Neurology ${ }^{\circledR}$ is the official journal of the American Academy of Neurology. Published continuously since 1951, it is now a weekly with 48 issues per year. Copyright () 2019 American Academy of Neurology. All rights reserved. Print ISSN: 0028-3878. Online ISSN: 1526-632X.

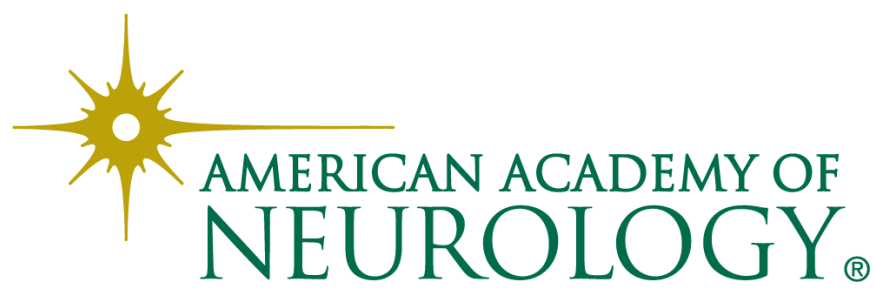

